\begin{tabular}{|l|l|l||}
\hline \multicolumn{2}{|c|}{ PublisherInfo } \\
\hline \hline PublisherName & $:$ & Palgrave Macmillan UK \\
\hline \hline PublisherLocation & $:$ & London \\
\hline \hline PublisherImprintName & $:$ & Palgrave Macmillan \\
\hline
\end{tabular}

\title{
Methods explained: forecasting
}

\begin{tabular}{||l|l|l||}
\hline \multicolumn{2}{|c||}{ ArticleInfo } \\
\hline \hline ArticleDOI & $:$ & $10.1057 /$ palgrave.elmr.1410188 \\
\hline \hline ArticleCategory & $:$ & Feature \\
\hline \hline ArticleFirstPage & $:$ & 55 \\
\hline \hline ArticleLastPage & $:$ & 58 \\
\hline \hline & & $\begin{array}{l}\text { RegistrationDate }: 2007-12-17 \\
\text { OnlineDate } \quad: \quad 2007-12-17\end{array}$ \\
\hline ArticleHistory & $:$ & Crown copyright2007 \\
\hline \hline ArticleCopyright & $:$ &
\end{tabular}




\section{John Wood, ${ }^{\text {Aff1 }}$ \\ Duncan Elliott, ${ }^{\text {Aff1 }}$}

Outlines the contexts where foreecasts are required, describes the techniques used and examines some issues faced by ONS

The Office for National Statistics (ONS) often makes use of forecasts in the production of its statistical outputs. The purpose of this article is to outline the contexts where forecasts are required, to describe the techniques used and to examine some of the issues faced by ONS when forecasting.

The Full Text of this article can be found on the National Statistics website (http://www.statistics.gov.uk/cci/article.asp?id=1907). 